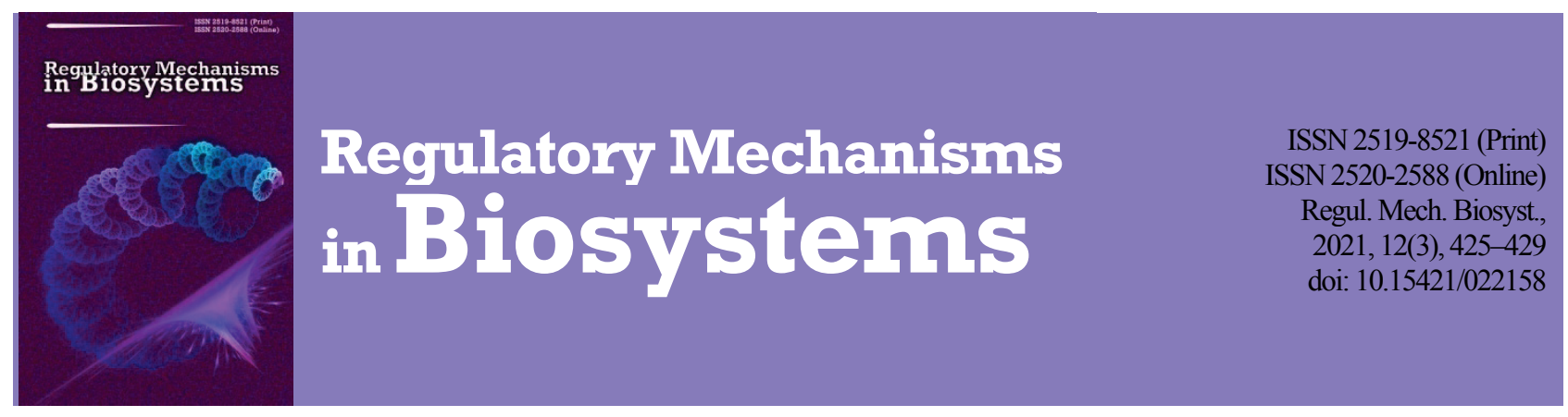

\title{
Serum clinical biochemical markers of Hy-Line W-36 laying hens under the influence of increased stocking densities in cages of multilevel batteries
}

\author{
Y. V. Osadcha, M. I. Sakhatsky, R. O. Kulibaba \\ The National University of Life and Environmental Sciences of Ukraine, Kyiv, Ukraine
}

Article info

Received 27.06.2021

Received in revised form 20.07.2021

Accepted 21.07.2021

National University of Life and Environmental Sciences of Ukraine, Heroyiv Oborony st., 15 Kyiv, 03041, Ukraine. Tel.: +38-044-527-82-05. E-mail: seledat@ukr.net

\author{
Osadcha, Y. V., Sakhatsky, M. I., \& Kulibaba, R. O. (2021). Serum clinical biochemical markers of Hy-Line W-36 laying hens under \\ the influence of increased stocking densities in cages of multilevel batteries. Regulatory Mechanisms in Biosystems, 12(3), 425-429. \\ doi:10.15421/022158
}

Today, the organism of hens is constantly exposed to numerous technological stressors in the conditions of industrial poultry farming, the least studied of which are long-term, which can cause the development of chronic stress. One of such stressors is the increased stocking density of hens, which is also a way of saving resources in egg poultry and is often used by producers to obtain more eggs per $1 \mathrm{~m}^{2}$ of poultry area. The aim of this study was to examine the effect of overcrowding, as a factor of chronic stress development, on the body of hens of a modern high-performance cross, which is necessary to select the best ways to keep them. Four groups of hens were formed for this purpose, which were kept at different stocking densities, according to European standards, Ukrainian standards and with increasing overcrowding. In this way, the gradually increasing intensity of the technological stressor was modeled. Long-term keeping of laying hens at high stocking density did not affect the content in the serum of total protein, albumin, urea and cholesterol, which were within the physiological norm. It was found that the increase in the stocking density of hens to Ukrainian standards, compared to the European, was accompanied by an increase in the activity of lactate dehydrogenase in the serum of their blood. With an increase in stocking density above European and Ukrainian standards, namely to $25.3 \mathrm{birds} / \mathrm{m}^{2}$, there was an increase in the activity of three enzymes - lactate dehydrogenase, aspartate aminotransferase and gamma-glutamyltransferase. It is proved that further overcompaction of hens to $26.7 \mathrm{birds} / \mathrm{m}^{2}$ is accompanied by an increase in serum glucose, creatinine, as well as a decrease in the ratio of calcium and phosphorus, which was confirmed by an increase in alkaline phosphatase activity. Also, increased activity of aspartate aminotransferase, lactate dehydrogenase and gamma-glutamyltransferase was observed. Thus, the main effects of chronic stress caused by prolonged keeping of hens at high stocking densities are reflected in the biochemical parameters of their serum, namely in the increase of glucose, creatinine, enzyme activity, as well as the violation of the ratio of calcium and phosphorus.

Keywords: laying hens; stocking density; chronic stress; glucose; creatinine; enzyme activity.

\section{Introduction}

The body of hens is constantly exposed to numerous technological stressors in the conditions of industrial production of poultry products (Ericsson et al., 2016; Hedlund et al., 2019). The action of stressors begins with the incubator (Hedlund \& Jensen, 2021) and accompanies the entire period of use of hens due to transportation, high stocking density, changes in the microclimate of production facilities and diet, vaccination, carrying out forced molting etc. (Bedanova et al., 2007; Kang et al., 2018; Gorelik et al., 2020). Technological stress reduces the level of immunological reactivity of the birds (Sloan et al., 2010; Hall et al., 2014), which leads to a decrease in their productivity (Lara \& Rostagno, 2013; Stoianovskyi et al., 2018; Goel, 2021) and leads to significant economic losses (Sakhatsky et al., 2020). At the same time, the increased stocking density of hens is both a technological stressor and a method of resource conservation in egg poultry, which is often used by producers to obtain more eggs from each $1 \mathrm{~m}^{2}$ of poultry area (Sakhatsky et al., 2020). Therefore, the study of the degree of physiological disorders in the body of hens caused by high stocking density is an urgent issue of poultry farming, and its solution will provide the opportunity to choose the best ways to keep laying hens.

It is known that during stress the activity of all the body systems of hens is strained, which is aimed at adaptation to new living conditions (Infante et al., 2017; Shevchuk et al., 2018). A prerequisite for the development of a stress response is the strengthening of the function of the endocrine glands and especially the hypothalamus - anterior pituitary adrenal cortex axis (Olubodun et al., 2015). The main role in the develop- ment of stress, according to Selye, is played by the adrenal cortex, which under the influence of the pituitary gland increases the secretion of steroid hormones involved in the process of adaptation (Selje, 1979). Therefore, it is believed that the main mechanisms in the implementation of stress in poultry are the sympathoadrenal and hypothalamic-pituitary-adrenocorticotropic (GGAC) systems, namely the development of adaptive responses to various nonspecific environmental factors is a common mechanism: through the hypothalamic-pituitary-adrenal axis and sympathoadrenal system involving catecholamines (Infante et al., 2017). Catecholamines ensure the transition of the body from a state of rest to a state of excitement due to their biological effects and allow it to stay in this state for a long time. At the same time, the occurrence and course of physiological reactions in poultry due to hormones of the adrenal medulla and mediators of the sympathoadrenal system is accompanied by increased and qualitative changes in metabolic processes in immunocompetent tissues (Stayanovsky et al., 2018), which is reflected in their blood. Leukocyte formula (ElLethey et al., 2000; Jiang et al., 2017; Liew \& Kubes, 2019) and the concentration of hormones in the blood (Scanes, 2016; Weimer et al., 2018) are usually used to diagnose stress, as well as the characteristics of hens' adaptation processes. Recently, some biochemical markers of blood serum have been actively used in poultry (Nwaigwe et al., 2020; RuizJimenez et al., 2021), which, in contrast to the leukocyte formula and hormonal status, allow us to describe the general physiological state of the body, adaptation processes (Kraus et al., 2021) and diagnose metabolic disorders of organs and tissues (Kudair \& Al-hussary, 2010; Koronowicz et al., 2016). In general, serum biochemical markers are indicators of hens' 
health and reflect any physiological or even pathological changes occurring in their body (Koronowicz et al., 2016). And any changes in their body affect not only the health of hens, but also inevitably affect their productivity (Pavlík et al., 2007). It is known that some changes in the values of various biochemical markers (glucose, total protein, albumin, enzyme activity) are associated with certain pathological processes in animals (Greene et al., 2013; Mollahosseini et al., 2017; Zhang et al., 2019). Therefore, the aim of this study was to examine the physiological changes in the body of laying hens due to increased stocking density based on the analysis of the markers of the clinical biochemistry of serum, as well as to determine the physiological limit of permissible overcrowding.

\section{Materials and methods}

Hy Line W-36 commercial egg layers were used as the object of research. Experiments were performed with experimental animals in accordance with the rules of the European Convention for the Protection of Vertebrate Animals (Official Journal of the European Union L276/33, 2010), as well as the Law of Ukraine "On protection of animals from cruelty" of 21.02.2006, No. 3447-IV.

Four groups of hens were formed in the conditions of a modern complex for production of food eggs, each of which was kept in a separate poultry house-analogue on the area $\left(2640 \mathrm{~m}^{2}\right)$ equipped with 12-tier cage batteries "Salmet" (Germany), consisting of 18144 cages with an area of $7506 \mathrm{~cm}^{2}(120 \times 62.55 \mathrm{~cm})$.

Chronic stress was simulated by 34-week keeping of hens, namely from the beginning of laying (at 18 weeks of age) to 52 weeks of age, at different stocking densities. The stocking densities I group of hens met the European standards and requirements of the cross-country developer (HyLine W-36 Final Hybrid Content Guide, 2019) - in the range of 13 $20 \mathrm{birds} / \mathrm{m}^{2}$ (490-750 $\mathrm{cm}^{2} /$ bird), the II group - Ukrainian standards (VNTP-APK-04.05.) - within 22-25 birds $/ \mathrm{m}^{2}$ (area $-400-450 \mathrm{~cm}^{2} / \mathrm{bird}$ ), and hens of the III and IV groups were kept with increasing overcrowding (Table 1). In this way, the gradually increasing intensity of the technological stressor was modeled.

\section{Table 1}

The scheme of the experiment to determine the effect of increased stocking density on serum clinical biochemical markers in cages of multilevel batteries

\begin{tabular}{lcccc}
\hline \multirow{2}{*}{ Characteristic } & \multicolumn{4}{c}{ Group of laying hens } \\
\cline { 2 - 5 } & I & II & III & IV \\
\hline Number of hens in the cage & 10 & 18 & 19 & 20 \\
Number of hens in the group, thousand & 181440 & 326592 & 344736 & 362880 \\
Stocking density, birds $/ \mathrm{m}^{2}$ & 13.3 & 24.0 & 25.3 & 26.7 \\
Provision of area, $\mathrm{cm}^{2} / \mathrm{bird}$ & 750.6 & 417.0 & 395.1 & 375.3 \\
Feeding front, $\mathrm{cm}$ & 12.0 & 6.7 & 6.3 & 6.0 \\
\hline
\end{tabular}

Hens were provided with drinking water, complete feed (Table 2) during the experiment and kept in accordance with the requirements (VNTP-APK-04.05).

Thirty blood samples were taken from laying hens of each group at the age of 18 weeks (at the beginning of the study) and at 52 weeks. 1.0 $1.5 \mathrm{~mL}$ of blood was taken from the axillary vein in an EDTA tube. Biochemical markers and activity of serum enzymes of laying hens were determined on a biochemical analyzer BioChem FC-360 (High Technology Inc., USA), namely the content of total protein, albumin, glucose, creatinine, urea, cholesterol, phosphorus, calcium, alanine aminotransferase activity, aspartate aminotransferase, alkaline phosphatase, lactate dehydrogenase and gamma-glutamyltransferase in the laboratory "Bald" (certificate No. LB/02/2016). Commercial diagnostic kits (High Technology Inc., USA) were used for determination of glucose - HT-G242 (method: oxidase, endpoint; wavelength $-500 \mathrm{~nm}$ ), total proteins - HT-T251 (method: biuret, endpoint; wavelength - $540 \mathrm{~nm}$ ), albumin - HT-A203 (method: bromocresol green, endpoint; wavelength $-630 \mathrm{~nm}$ ), creatinine - HT-C225 (method: Jaffe, kinetics; wavelength - $510 \mathrm{~nm}$ ), urea HT-U254 (method: Trinder/uricase, endpoint; wavelength - $520 \mathrm{~nm}$ ), cholesterol - HT-C218 (method: enzymatic, endpoint; wavelength $500 \mathrm{~nm}$ ), phosphorus - HT-P244 (method: ammonium molybdate, endpoint; wavelength - $340 \mathrm{~nm}$ ), calcium - HT-C216 (method: OKF, end- point; wavelength - $570 \mathrm{~nm}$ ), alanine aminotransferase - HT-A206 (method: IFCC, kinetics; wavelength $-340 \mathrm{~nm}$ ), aspartate aminotransferase HT-A109 (method: IFCC, kinetics; wavelength - $340 \mathrm{~nm}$ ), alkaline phosphatase - HT-A205 (method: kinetics; wavelength - $405 \mathrm{~nm}$ ), lactate dehydrogenase - HT-L236 (method: Modified Wacker/Tris method, kinetics; wavelength $-340 \mathrm{~nm}$ ), gamma-glutamyltransferase - (method: kinetics; wavelength $-405 \mathrm{~nm}$ ). Concentration of the biochemical constituents was calculated according to the manufacture instruction. Reference values biochemical markers and activity of serum enzymes of laying hens according to Nasonov et al. (2014).

Table 2

The composition of feed for laying hens in the productive period (\%)

\begin{tabular}{|c|c|c|c|c|}
\hline \multirow{2}{*}{ Component } & \multicolumn{4}{|c|}{ Egg-laying intensity, $\%$} \\
\hline & $95-100$ & 93 & 88 & 85 \\
\hline Wheat & 20.418 & 19.336 & 12.000 & 10.566 \\
\hline Com & 37.053 & 45.399 & 54.330 & 52.334 \\
\hline Sunflower meal & 20.754 & 22.278 & 18.166 & 23.533 \\
\hline Soybean meal & 7.000 & 0 & 3.000 & 0 \\
\hline Soybean oil & 0.959 & 0.661 & 0 & 0.500 \\
\hline Shell 0-3 mm & 10.701 & 9.922 & 10.25 & 11.088 \\
\hline Salt & 0.210 & 0.200 & 0.200 & 0.210 \\
\hline Monocalcium phosphate & 1.193 & 0.811 & 0.805 & 0.532 \\
\hline Sodium sulfate & 0.160 & 0.117 & 0.120 & 0.095 \\
\hline Methionine & 0.186 & 0.105 & 0.088 & 0.076 \\
\hline Lysine sulfate & 0.637 & 0.585 & 0.516 & 0.579 \\
\hline Threonine & 0.127 & 0.095 & 0.057 & 0.065 \\
\hline Loxidan TD 100 & 0 & 0.010 & 0 & 0 \\
\hline Millersheim & 0.013 & 0.015 & 0.011 & 0 \\
\hline Globamax 1000 & 0.100 & 0 & 0 & 0 \\
\hline ProActive & 0 & 0 & 0.150 & 0.150 \\
\hline Enteronormin Detox & 0.150 & 0.150 & 0 & 0 \\
\hline Mastersorb & 0.150 & 0.130 & 0.130 & 0 \\
\hline Mycocide Pro & 0 & 0 & 0 & 0.090 \\
\hline Choline chloride & 0.050 & 0.050 & 0.040 & 0.035 \\
\hline Cronozyme & 0 & 0 & 0 & 0.011 \\
\hline Yellow carnation & 0.003 & 0.003 & 0.003 & 0.003 \\
\hline Red carnation & 0.003 & 0.003 & 0.003 & 0.003 \\
\hline Mineral complex & 0.100 & 0.100 & 0.100 & 0.100 \\
\hline Vitamin complex & 0.033 & 0.030 & 0.030 & 0.030 \\
\hline Together & 100.000 & 100.000 & 100.000 & 100.000 \\
\hline
\end{tabular}

Significance of group differences was assessed using one-way analysis of variance (ANOVA) and Tukey-Cramer multiple comparison test as a post-hoc test tool. The data in the tables are presented in the form of $x \pm$ $\mathrm{SD}$ (mean \pm standard deviation). Verification of the distribution of sample data for normality was performed according to the Kolmogorov-Smirnov test. The nonparametric Mann-Whitney U-test was used if the data distribution was significantly different from normal. Differences between groups were considered significant at $\mathrm{P}<0.05$.

\section{Result}

Biochemical markers of blood serum of hens of all experimental and control groups at the beginning of the study were within physiological norms for each parameter. No significant differences were found between the groups. At the same time, long-term keeping of laying hens at high stocking density also did not affect the content in the serum of total protein, albumin, urea and cholesterol (Table 3), which were within the physiological norm. The content of creatinine and glucose was within the physiological norm in the serum of I-III groups of hens, with their stocking density of 13.3 to $25.3 \mathrm{birds} / \mathrm{m}^{2}$. The highest glucose content was found in the IV group of hens, with their stocking density of $26.7 \mathrm{birds} / \mathrm{m}^{2}$, exceeding the upper limit of the physiological norm by $9.1 \%$. The glucose content in the serum of hens of the IV group was higher by $20.0 \%$ compared to the I group, by $22.4 \%$ and $21.6 \%$ compared to the II and III groups. The content of creatinine in the serum of hens of the IV group exceeded the upper limit of physiological norm by $6.7 \%$ and was higher by $27.2 \%$ compared to the I group and by $23.1 \%$ compared to the II and III in groups.

The content of calcium in the serum of hens of all groups was within the physiological norm. In the IV group of hens its amount was lower by $5.3 \%$ compared to the I and III groups, and by $6.6 \%$ compared to the 
II group. The content of phosphorus in the serum of the IV group exceeded the physiological norm by $11.8 \%$ and was higher by $74.5 \%$ compared to the I group and by $59.7 \%$ and $54.7 \%$ compared to groups II and III.

\section{Table 3}

Biochemical profile of blood serum of laying hens under the influence of increased stocking densities ( $x \pm \mathrm{SD}, \mathrm{n}=30$ /group)

\begin{tabular}{|c|c|c|c|c|c|}
\hline \multirow{2}{*}{ Marker } & \multicolumn{4}{|c|}{ Group of laying hens } & \multirow{2}{*}{$\begin{array}{c}\text { Reference } \\
\text { values }\end{array}$} \\
\hline & $\mathrm{I}$ & II & III & IV & \\
\hline Total protein, $\mathrm{g} / \mathrm{L}$ & $57.2 \pm 4.4^{\mathrm{a}}$ & $55.4 \pm 6.9^{\mathrm{a}}$ & $54.1 \pm 2.5^{\mathrm{a}}$ & $57.1 \pm 5.9^{\mathrm{a}}$ & $37.8-59.0$ \\
\hline Albumin, $\mathrm{g} / \mathrm{L}$ & $18.7 \pm 1.2^{\mathrm{a}}$ & $16.4 \pm 1.1^{\mathrm{a}}$ & $19.4 \pm 0.5^{\mathrm{a}}$ & $17.8 \pm 0.8^{\mathrm{a}}$ & $15.0-25.0$ \\
\hline Glucose, $\mathrm{mmol} / \mathrm{L}$ & $15.0 \pm 1.5^{\mathrm{a}}$ & $14.7 \pm 2.2^{\mathrm{a}}$ & $14.8 \pm 0.6^{\mathrm{a}}$ & $18.0 \pm 0.8^{b}$ & $10.0-16.5$ \\
\hline Creatinine, $\mu \mathrm{mol} / \mathrm{L}$ & $22.4 \pm 1.8^{\mathrm{a}}$ & $23.4 \pm 3.6^{\mathrm{a}}$ & $23.4 \pm 2.7^{\mathrm{a}}$ & $28.8 \pm 1.1^{\mathrm{b}}$ & $22.0-27.0$ \\
\hline Urea, $\mathrm{mmol} / \mathrm{L}$ & $1.0 \pm 0.2^{\mathrm{a}}$ & $0.9 \pm 0.1^{\mathrm{a}}$ & $0.9 \pm 0.3^{\mathrm{a}}$ & $1.0 \pm 0.1^{\mathrm{a}}$ & $0.7-2.4$ \\
\hline Cholesterol, $\mathrm{mmol} / \mathrm{L}$ & $3.5 \pm 1.1^{\mathrm{a}}$ & $2.3 \pm 0.3^{\mathrm{a}}$ & $3.9 \pm 1.1^{\mathrm{a}}$ & $3.4 \pm 0.3^{\mathrm{a}}$ & $2.0-4.0$ \\
\hline Phosphorus, $\mathrm{mmol} / \mathrm{L}$ & $1.4 \pm 0.3^{\mathrm{a}}$ & $\begin{array}{l}1.5 \pm \\
0.4^{\mathrm{a}}\end{array}$ & $\begin{array}{l}1.6 \pm \\
0.4^{\mathrm{a}}\end{array}$ & $2.5 \pm 0.2^{\mathrm{b}}$ & $1.2-2.2$ \\
\hline Calcium, $\mathrm{mmol} / \mathrm{L}$ & $4.5 \pm 0.4^{\mathrm{a}}$ & $\begin{array}{c}4.6 \pm \\
0.9^{\mathrm{a}}\end{array}$ & $\begin{array}{c}4.5 \pm \\
0.1^{\mathrm{a}}\end{array}$ & $4.3 \pm 0.3^{b}$ & $2.8-4.6$ \\
\hline Calcium/phosphorus & $3.4 \pm 1.1^{\mathrm{a}}$ & $3.0 \pm 0.6^{\mathrm{a}}$ & $3.0 \pm 0.8^{\mathrm{a}}$ & $1.8 \pm 0.2^{\mathrm{b}}$ & $3.0-3.8: 1$ \\
\hline
\end{tabular}

Note: ${ }^{\text {a }},{ }^{\mathrm{b}}{ }^{\mathrm{c}}$-indicate values that significant differed in one row of the Table $\mathrm{P}<0.05$.
Violation of the ratio of macronutrients especially important for laying hens - calcium and phosphorus, confirms the change in the serum of alkaline phosphatase activity (Table 4). There is an increase in the activity of alkaline phosphatase with increasing stocking density of hens. Its highest activity was found in hens of the IV group with excess over the upper limit of the physiological norm by $19.5 \%$, while the values of hens of IIII groups were within the physiological norm. The activity of alkaline phosphatase in the serum of hens of the IV group was higher by $44.9 \%$ compared to the I group and by $32.9 \%$ and $27.6 \%$ compared to the II and III groups.

In proportion to the increase in the stocking density of hens, there was an increase in the activity of other enzymes in their serum. Excess over the upper limit of the physiological norm of aspartate aminotransferase activity was observed in the II group of hens, at Ukrainian normative density by $1.0 \%$, and for overcompaction - in the III group - by $18.3 \%$ and in IV group - by $23.7 \%$. The activity of gamma-glutamyltransferase in the IV group of hens was higher by $35.6 \%$ than in the I group and by $34.4 \%$ and $24.4 \%$ - in the II and III groups. The level of lactate dehydrogenase in the serum of the IV group of hens was higher by $43.1 \%$ compared to the I group and by $26.8 \%$ and $22.2 \%$ compared to the II and III groups.

Table 4

Activity of serum enzymes of laying hens under the influence of increased stocking densities (units/L, $x \pm S D, n=30$ )

\begin{tabular}{|c|c|c|c|c|c|}
\hline \multirow{2}{*}{ Marker } & \multicolumn{4}{|c|}{ Group of laying hens } & \multirow{2}{*}{ Reference values } \\
\hline & $\mathrm{I}$ & II & III & IV & \\
\hline Alanine aminotransferase & $1.0 \pm 0.3^{\mathrm{a}}$ & $0.8 \pm 0.4^{\mathrm{a}}$ & $0.6 \pm 0.3^{\mathrm{a}}$ & $1.0 \pm 0.1^{\mathrm{a}}$ & $13.0-26.5$ \\
\hline Aspartate aminotransferase & $208.6 \pm 32.3^{\mathrm{a}}$ & $212.2 \pm 30.7^{\mathrm{a}}$ & $248.4 \pm 17.7^{b}$ & $259.8 \pm 12.7^{\mathrm{c}}$ & $125-210$ \\
\hline Gamma-glutamyltransferase & $22.2 \pm 6.1^{\mathrm{a}}$ & $22.4 \pm 5.7^{\mathrm{ab}}$ & $24.2 \pm 4.1^{\mathrm{b}}$ & $30.1 \pm 7.6^{\mathrm{c}}$ & $*$ \\
\hline Alkaline phosphatase & $684.8 \pm 125.2^{\mathrm{a}}$ & $746.4 \pm 128.3^{\mathrm{b}}$ & $777.6 \pm 129.5^{\mathrm{b}}$ & $992.2 \pm 133.9^{c}$ & $350-830$ \\
\hline Lactate dehydrogenase & $1908.8 \pm 160.3^{\mathrm{a}}$ & $2154.8 \pm 199.2^{b}$ & $2235.6 \pm 202.9^{b}$ & $2731.9 \pm 271.3^{\mathrm{c}}$ & $636-1960$ \\
\hline
\end{tabular}

Note: ${ }^{\text {a }}{ }^{\mathrm{b}},{ }^{\mathrm{c}}$ - indicate values that significant differed in one row of the table $(\mathrm{P}<0.05) ;{ }^{*}$-reference values are not available for laying hens.

\section{Discussion}

The increase in the stocking density of hens from 13.3 to $25.3 \mathrm{birds} / \mathrm{m}^{2}$ did not affect the biochemical profile of their serum, while overcompaction to $26.7 \mathrm{birds} / \mathrm{m}^{2}$ was accompanied by an increase in glucose levels of $22.4 \%$ with an excess of physiological norm by $9.1 \%$. In our opinion, the increase of serum glucose occurs due to increased destructive processes in hens under conditions of overcompaction, as well as the action of hormones - glucocorticoids and catecholamines (Downing, 2012; Kraus et al., 2021). The findings are consistent with the results of other studies describing hyperglycemia as a reaction of the birds to chronic (González \& Silva, 2006; Gupta et al., 2017; Kraus et al., 2021) and acute stress (Virden \& Kidd, 2009; Mert \& Yildirim, 2016), as well as the experimental introduction of adrenocorticotropic hormone (Puvadolpirod \& Thaxton, 2000; Odihambo Mumma et al., 2006). Research conducted by Kang et al. $(2006,2018)$ with co-authors confirms that increasing the stocking density from 5 to $10 \mathrm{birds} / \mathrm{m}^{2}$ of floor and from 13 to 19 birds $/ \mathrm{m}^{2}$ of aviary does not cause changes in serum glucose levels in laying hens. At the same time, there are reports that an increase in serum glucose is not observed with cyclic heat stressors (Laganá et al., 2007; Bueno et al., 2017).

In addition, Guo et al. (2012) noted an increase in serum creatinine in laying hens with increasing stocking density, which is confirmed by the study data. Thus, the increase in the density of hens to $26.7 \mathrm{birds} / \mathrm{m}^{2}$ was accompanied by an increase in serum creatinine by $27.2 \%$ in excess of the physiological norm by $6.7 \%$ (Goel, 2021). Bueno et al. (2017), who studied the response of broiler chickens to cyclic heat stress, as well as Abo Ghanima et al. (2020), who studied the response of ducks to increased stocking density, did not notice an increase in their creatinine levels.

The increase in the stocking density of hens was accompanied by an increase in serum levels of phosphorus by $74.5 \%$ and a violation of the ratio of calcium and phosphorus, which manifested itself in a decrease of $47.1 \%$ and was confirmed by changes in alkaline phosphatase activity, which at a density of $26.7 \mathrm{birds} / \mathrm{m}^{2}$ was higher by $44.9 \%$ and exceeded the physiological norm by $19.5 \%$. The data obtained confirm the results of Rajman et al. (2006), which described a stress-induced increase in alkaline phosphatase levels in the serum of chickens caused by limited access to feed. Also, the increase in alkaline phosphatase activity may be due not only to high egg production and excessive intake of phosphates with food (Al-Bustany et al., 1998), but also to the constant exposure to stressors (Onbaşlar et al., 2016).

Along with the increase, stocking density of hens was accompanied by a change in the activity in the serum of aspartate aminotransferase and lactate dehydrogenase, which reflects the violation of tissue integrity (activation of destructive processes) of poultry, especially liver (Mikami et al., 2004) and muscle (Lin et al., 2006; Sandercock et al., 2006). In particular, an increase in aspartate aminotransferase activity was observed already with an increase in stocking density to $25.3 \mathrm{birds} / \mathrm{m}^{2}-$ by $24.5 \%$ in excess of physiological norms. Similar results have been obtained by many researchers (Abudabos et al., 2013; Park et al., 2018; Kraus et al., 2021), who describe the increase in the activity of aspartate aminotransferase as a reaction of the chickens to the action of technological stressors. According to Capitelli \& Crosta (2013) and Campbell et al. (2004), an increase in aspartate aminotransferase activity above 275 units/L indicates liver and muscle dysfunction and only excess levels activity of 800 units/L is evidence of severe liver damage. Obviously, in this study, the increase in aspartate aminotransferase activity to 259.8 units/L under the influence of overcrowding of hens is caused by their being kept in a constant state of neuromuscular tension. According to Everds et al. (2013), constant stress leads to an increase in the activity of aspartate aminotransferase and at the same time to an increase in the concentration of glucose in the serum of hens kept in cages, which is confirmed by the study data.

Scientists explain the increase in lactate dehydrogenase activity due to muscle destruction during neuromuscular tension (Sandercock et al., 2006), which in these studies was observed starting with a retention density of $24.0 \mathrm{birds} / \mathrm{m}^{2}$ - by $12.9 \%$ and overcompaction to $26.7 \mathrm{birds} / \mathrm{m}^{2}$ - by $43.1 \%$ in excess of the physiological norm by $39.4 \%$. The increase in lactate dehydrogenase as a result of acute heat stress has also been described by Xie et al. (2015).

The increase in the activity of gamma-glutamyltransferase in the serum of hens was observed when the stocking density increased to 25.3 birds $/ \mathrm{m}^{2}$ and further increases in proportion to the increasing over- 
compaction by $9.0-35.6 \%$. The obtained results confirm the data of other authors, which described the increase in gamma-glutamyltransferase as a response of broiler chickens to cyclic heat stress (Bueno et al., 2017). Gamma-glutamyltransferase in chickens is found mainly in the liver, pancreas and kidneys according to Radin (2003). The increase in gammaglutamyltransferase activity in blood serum is due to its increase in the liver, because in the kidneys gamma-glutamyltransferase is localized on the luminal surface of proximal renal tubules and in the case of enzyme damage gets directly into the urine and is excreted with it at the same time, according to González \& Silva (2006). The authors also emphasize that the function of gamma-glutamyltransferase is associated with the metabolism of glutathione, and its increase may indicate cholestasis and proliferation of bile ducts in the liver of birds.

\section{Conclusions}

Long-term keeping of laying hens at high stocking density did not affect the content in the serum of total protein, albumin, urea and cholesterol. The increase in stocking density of hens to $24.0 \mathrm{birds} / \mathrm{m}^{2}$ was accompanied only by an increase in the activity of lactate dehydrogenase in their blood serum by $12.9 \%$. A further increase in stocking density to $25.3 \mathrm{birds} / \mathrm{m}^{2}$ led to an increase in the activity of three enzymes - lactate dehydrogenase - by $17.1 \%$, aspartate aminotransferase - by $19.1 \%$ and gamma-glutamyltransferase - by $9.0 \%$. Overcompaction of hens to $26.7 \mathrm{birds} / \mathrm{m}^{2}$ was accompanied by an increase of glucose levels by $22.4 \%$, creatinine - by $27.2 \%$, phosphorus $-74.5 \%$, as well as a decrease in the ratio of calcium and phosphorus by $47.1 \%$, which is confirmed by an increase in alkaline phosphatase activity by $44.9 \%$. Also, with overcompaction of hens to $26.7 \mathrm{birds} / \mathrm{m}^{2}$, there was an increase in the activity of aspartate aminotransferase by $24.5 \%$, lactate dehydrogenase - by $43.1 \%$ and gamma-glutamyltransferase - by $35.6 \%$. Thus, the main effects of chronic stress caused by prolonged keeping of hens at high stocking densities are reflected in the biochemical markers of their serum, namely in the increase of glucose, creatinine, phosphorus, enzyme activity, as well a violation of the ratio of calcium and phosphorus.

\section{References}

Abo Ghanima, M. M., Abd El-Hack, M. E., Taha, A. E., Tufarelli, V., Laudadio, V., \& Naiel, M. A. (2020). Assessment of stocking rate and housing system on performance, carcass traits, blood indices, and meat quality of French Pekin ducks. Agriculture, 10(7), 273.

Abudabos, A. M., Samara, E. M., Hussein, E. O., Al-Ghadi, M. A. Q., \& Al-Atiyat, R. M. (2013). Impacts of stocking density on the performance and welfare of broiler chickens. Italian Journal of Animal Science, 12, 66-71.

Al-Bustany, Z., Al-Athariandy, A. K., \& Abdul-Hassan, A. (1998). Plasma alkaline phosphatase and production traits in laying hens as inuenced by dietary protein, strain and age. British Poultry Science, 39, 568-571.

Bedanova, I., Voslarova, E., Chloupek, P., Pistekova, V., Suchy, P., Blahova, J., Dobsikova, R., \& Vecerek, V. (2007). Stress in broilers resulting from shackling. Poultry Science, 86(6), 1065-1069.

Bueno, J. P., Nascimento, M. R., Martins, J., Marchini, C. F., Gotardo, L. R., Sousa, G. R., Mundim, A. V., Guimarães, E., \& Rinaldi, F. P. (2017). Effect of age and cyclical heat stress on the serum biochemical profile of broiler chickens. Semina-Ciencias Agrarias, 38(3), 1383-1392.

Campbell, T. W. (2004). Clinical chemistry of birds. In: Thrall, M. A., Baker, D. C., Campbell, T. W., DeNicola, D., Fettman, M. J., Lassen, E. D., Rebar, A., \& Weiser, G. Veterinary hematology and clinical chemistry. Lippincott Williams \& Wilkins, Philadelphia.

Capitelli, R., \& Crosta, L. (2013). Overview of psittacine blood analysis and comparative retrospective study of clinical diagnosis, hematology and blood chemistry in selected psittacine species. Veterinary Clinics of North America: Exotic Animal Practice, 16(1), 71-120.

Downing, J. (2012). On-invasive assessment of stress in commercial housing systems. Australian Egg Corporation Limited, North Sydney.

El-Lethey, H., Aerni, V., Jungi, T., \& Wechsler, B. (2000). Stress and feather pecking in laying hens in relation to housing conditions. British Poultry Science, 41(1), 22-28.

Ericsson, M., Henriksen, R., Bélteky, J., Sundman, A. S., Shionoya, K., \& Jensen, P. (2016). Long-term and transgenerational effects of stress experienced during different life phases in chickens (Gallus gallus). PloS One, 11(4), e0153879.

Everds, N. E., Snyder, P. W., Bailey, K. L., Bolon, B., Creasy, D. M., Foley, G. L., Rosol, T. J., \& Sellers, T. (2013). Interpreting stressresponses during routine to- xicity studies: A review of the biology, impact, and assessment. Toxicologic Pathology, 41, 560-614.

Goel, A. (2021). Heat stress management in poultry. Journal of Animal Physiology and Animal Nutrition, in print.

González, F. H. D., \& Silva, S. C. (2006). Introdução à bioquímica clínica veterinária. 2nd ed. Universidade Federal do Rio Grande do Sul, Porto Alegre.

Gorelik, O., Harlap, S., Derkho, M., Dolmatova, I., Eliseenkova, M., Vinogradova, N., Knysh, I., Ermolov, S., Burkov, P., Lopaeva, N., Bezhinar, T., Ali Shariati, M., \& Rebezov, M. (2020). Influence of transport stress on the adaptation potential of chickens. Ukrainian Journal of Ecology, 10(2), 260-263.

Greene, S. J., Gheorghiade, M., Vaduganathan, M., Ambrosy, A. P., Mentz, R. J., Subacius, H., Maggioni, A. P., Nodari, S., Konstam, M. A., Butler, J., \& Filippatos, G. (2013). Everest trial investigators. Haemoconcentration, renal function, and post-discharge outcomes among patients hospitalized for heart failure with reduced ejection fraction: Insights from the Everest trial. European Journal of Heart Failure, 15(12), 1401-1411.

Guo, Y., Song, Z., Jiao, H., Song, Q., \& Lin, H. (2012). The effect of group size and stocking density on the welfare and performance of hens housed in furnished cages during summer. Animal Welfare Journal, 21, 41-49.

Gupta, S. K., Behera, K., Pradhan, C. R., Acharya, A. P., Sethy, K., Behera, D., Lone1, S. A., \& Shinde, K. P. (2017). Influence of stocking density on the performance, carcass characteristics, hemato-biochemical indices of Vanaraja chickens. Indian Journal of Animal Research, 51(5), 939-943.

Hall, J. M., Witter, A. R., Racine, R. R., Berg, R. E., Podawiltz, A., Jones, H., \& Mummert, M. E. (2014). Chronic psychological stress suppresses contact hypersensitivity: Potential roles of dysregulated cell trafficking and decreased IFN- $\gamma$ production. Brain, Behavior and Immunity, 36, 156-164.

Hedlund, L., \& Jensen, P. (2021). Incubation and hatching conditions of laying hen chicks explain a large part of the stress effects from commercial large-scale hatcheries. Poultry Science, 100(1), 1-8.

Hedlund, L., Whittle, R., \& Jensen, P. (2019). Effects of commercial hatchery processing on short- and long-term stress responses in laying hens. Scientific Reports, $9,1-10$.

Infante, M., Armani, A., Mammi, C., Fabbri, A., \& Caprio, M. (2017). Impact of adrenal steroids on regulation of adipose tissue. Comprehensive Physiology, 7(4), 1425-1447.

Jiang, W., Li, Y., Sun, J., Li, L., Li, J. W., Zhang, C., Huang, C., Yang, J., Kong, G. Y., \& Li, Z. F. (2017). Spleen contributes to restraint stress induced changes in blood leukocytes distribution. Scientific Reports, 7, 6501.

Kang, H. K., Park, S. B., Jeon, J. J., Kim, H. S., Kim, C. H., Hong, E., \& Kim, C. H. (2018). Effect of stocking density on laying performance, egg quality and blood parameters of Hy-Line Brown laying hens in an aviary system. European Poultry Science, 82.

Kang, H. K., Park, S. B., Kim, H. S., \& Kim, C. H. (2016). Effects of stock density on the laying performance, blood parameter, corticosterone, litter quality, gas emission and bone mineral density of laying hens in floor pens. Poultry Science, 95, 2764-2770.

Koronowicz, A. A., Banks, P., Szymczyk, B., Leszczyńska, T., Master, A., Piasna, E., Szczepański, W., Domagała, D., Kopeć, A., Piątkowska, E., \& Laidler, P. (2016). Dietary conjugated linoleic acid affects blood parameters, liver morphology and expression of selected hepatic genes in laying hens. British Poultry Science, 57(5), 663-673.

Kraus, A., Zita, L., Krunt, O., Härtlová, H., \& Chmelíková, E. (2021). Determination of selected biochemical parameters in blood serum and egg quality of Czech and Slovak native hens depending on the housing system and hen age. Poultry Science, 100(2), 1142-1153.

Kudair, I. M., \& Al-hussary, N. A. J. (2010). Effect of vaccination on some biochemical parameters in broiler chickens. Iraqi Journal of Veterinary Sciences, 24, $59-64$.

Laganá, C., Ribeiro, A. M. L., González, F. H. D., Lacerda, L. A., Kratz, L. R., \& Barboza, P. R. (2007). Niveis dietéticos de proteina e gordura e parâmetros bioquimicos, hematológicos e empenamento em frangos de corte estressados pelo calor. Revista Brasileira de Zootecnia, 36(6), 1783-1790.

Lara, L. J., \& Rostagno, M. H. (2013). Impact of heat stress on poultry production. Animals, 3(2), 356-369.

Liew, P. X., \& Kubes, P. (2019). The neutrophil's role during health and disease. Physiological Reviews, 99(2), 1223-1248.

Lin, H., Decuypere, E., \& Buyse, J. (2006). Acute heat stress induces oxidative stress in broiler chickens. Comparative Biochemistry and Physiology, 144, 11-17.

Mert, N. I., \& Yildirim, B. A. (2016). Biochemical parameters and histopathological findings in the forced molt laying hens. Brazilian Journal of Poultry Science, 18(4), 711-718.

Mikami, T., Sumida, S., Ishibashi, Y., \& Ohta, S. (2004). Endurance exercise training inhibits activity of plasma GOT and liver caspase- 3 of mice [correction of rats] exposed to stress by induction of heat shock protein 70. Joumal of Applied Physiology, 96, 1776-1781.

Mollahosseini, M., Daneshzad, E., Rahimi, M. H., Yekaninejad, M. S., Maghbooli, Z., \& Mirzaei, K. (2017). The association between fruit and vegetable intake 
and liver enzymes (aspartate and alanine transaminases) in Tehran, Iran. Ethiopian Journal of Health Sciences, 27(4), 401-410.

Nasonov, I. V., Buyko, N. V., Lizun, R. P., Volyihina, V. E., Zaharik, N. V., \& Yakubovskiy, S. M. (2014). Metodicheskie rekomendatsii po gematologicheskim biohimicheskim issledovaniyam u kur sovremennyih krossov [Methodological recommendations on haematological and biochemical researches on modern chicked crosses]. S. N. Vyshelessky Institute of Experimental Veterinary Medicine, Minsk (in Russian).

Nwaigwe, C. U., Ihedioha, J. I., Shoyinka, S. V., \& Nwaigwe, C. O. (2020). Evaluation of the hematological and clinical biochemical markers of stress in broiler chickens. Veterinary World, 13(10), 2294-2300.

Odihambo Mumma, J., Thaxton, J. P., Vizzier-Thaxton, Y., \& Dodson, W. L. (2006). Physiological stress in laying hens. Poultry Science, 85(4), 761-769.

Olubodun, J., Zulkifli, I., Hair-Bejo, M., Kasim, A., \& Soleimani, A. F. (2015). Physiological response of glutamine and glutamic acid supplemented broiler chickens to heat stress. European Poultry Science, 79, 1-12.

Onbaşlar, E. E., Erdem, E., Ünal, N., Tunç, A. S., Kocakaya, A., \& Yaranoğlu, B. (2016). Comparison of liver and bone health of two laying hen strains kept in different cage systems. European Poultry Science, 80

Park, B.-S., Um, K.-H., Park, S.-O., \& Zammit, V. A. (2018). Effect of stocking density on behavioral traits, blood biochemical parameters and immune responses in meat ducks exposed to heat stress. Archives Animal Breeding, 61, 425-432.

Pavlík, A., Pokludová, M., Zapletal, D., \& Jelínek, P. (2007). Effects of housing systems on biochemical indicators of blood plasma in laying hens. Acta Veterinaria Brno, 76, 339-347.

Puvadolpirod, S., \& Thaxton, J. P. (2000). Model of physiological stress in chickens 1. Response parameters. Poultry Science, 79(3), 363-369.

Radin, M. J. (2003). Interpretação de perfis bioquímicos. In: Fenner, W. R. Consulta rápida em clínica veterinária. Editora Guanabara, Rio de Janeiro.

Rajman, M., Juráni, M., Lamosová, D., Mácajová, M., Sedlacková, M., Kostál, L., Jezová, D., \& Výboh, P. (2006). The effects of feed restriction on plasma biochemistry in growing meat type chickens (Gallus gallus). Comparative Biochemistry and Physiology, 145(3), 363-371.

Ruiz-Jimenez, F., Gruber, E., Correa, M., \& Crespo, R. (2021). Comparison of portable and conventional laboratory analyzers for biochemical tests in chickens. Poultry Science, 100(2), 746-754
Sakhatsky, M., Osadcha, Y., \& Kuchmistov, V. (2020). Reaction of the reproductive system of hens to the chronic stressor. Ukrainian Journal of Ecology, 10(4), 6-11.

Sandercock, D. A., Hunter, R. R., Mitchell, M. A., \& Hocking, P. M. (2006). Thermoregulatory capacity and muscle membrane integrity are compromised in broilers compared with layers at the same age or body weight. British Poultry Science, 47, 322-329.

Scanes, C. G. (2016). Biology of stress in poultry with emphasis on glucocorticoids and the heterophil to lymphocyte ratio. Poultry Science, 95(9), 2208-2215.

Selye, H. (1979). Stress without distress. Progres, Moscow.

Shevchuk, M., Stoyanovskyy, V., \& Kolomiiets, I. (2018). Technological stress in poultry. Scientific Messenger of LNU of Veterinary Medicine and Biotechnologies, Series Veterinary Sciences, 20(88), 63-68.

Sloan, E. K., Priceman, S. J., Cox, B. F., Yu, S., Pimentel, M. A., Tangkanangnukul, V., Arevalo, J. M., Morizono, K., Karanikolas, B. D., Wu, L., Sood, A. K., \& Cole, S. W. (2010). The sympathetic nervous system induces a metastatic switch in primary breast cancer. Cancer research, 70(18), 7042-7052

Stoianovskyi, V. H., Kolomiiets, I. A., Harmata, L. S., \& Kamratska, O. I. (2018). Zminy morfofunktsionalnoho stanu orhaniv endokrynnoji ta imunnoji system perepeliv promyslovoho vyroshchuvannia za diji stresu [Changes in the morphofunctional state of the endocrine and immune systems of quails in industrial cultivation under stress]. Physiological Journal, 64(1), 25-33 (in Ukrainian)

Virden, W., \& Kidd, M. (2009). Physiological stress in broilers: Ramifications on nutrient digestibility and responses. The Journal of Applied Poultry Research, $18,338-347$

Weimer, S. L., Wideman, R. F., Scanes, C. G., Mauromoustakos, A., Christensen, K. D., \& Vizzier Thaxton, Y. (2018). An evaluation of methods for measuringstress in broiler chickens. Poultry Science, 97(10), 3381-3389.

Xie, J., Tang, L., Lu, L., Zhang, L., Lin, X., Liu, H.-C., Odle, J., \& Luo, X. (2015) Effects of acute and chronic heat stress on plasma metabolites, hormones and oxidant status in restrictedly fed broiler breeders. Poultry Science, 94(7), 1635-1644.

Zhang, J., Li, Q., Wu, Y., Wang, D., Xu, L., Zhang, Y., Wang, S., Wang, T., Liu, F , Zaky, M. Y., Hou, S., Liu, S., Zou, K., Lei, H., Zou, L., Zhang, Y., \& Liu, H. (2019). Cholesterol content in cell membrane maintains surface levels of ErbB2 and confers a therapeutic vulnerability in ErbB2-positive breast cancer. Cell Commun Signal, 17, 15 